\title{
Peran dan Fungsi E-Bisnis Dalam Bisnis Digital
}

\author{
Mohamad Zainudin \\ Faculty Of Computer Universitas Mitra Indonesia \\ mohamadzainudin.student@umitra.ac.id \\ NPM : 205100079P
}

Fungsi dari E-business adalah untuk mendukung bagian dari marketing, produksi, accounting, finance dan human resource management. Proses transaksi online memegang peranan yang sangat penting pada e-business. Perusahaan dapat menjalin komunikasi dengan konsumen secara rutin. Dengan demikian, perusahaan dapat mengetahui keinginan, kebutuhan dan tanggapan dari para konsumennya. Jaringan komunitas konsumen yang terbentuk akan menciptakan kumpulan para konsumen yang loyal serta memudahkan perusahaan dalam mendistribusikan informasi mengenai produk, yang berarti akan menghemat biaya promosi dan berpotensi meningkatkan jumlah konsumen.

Perusahaan dapat menjalin kerja sama yang lebih baik dengan para supplier, yaitu dengan membangun suatu Supply Chain Management. E-business mendukung pelaksanaan transaksi jarak jauh sehingga dapat menambah pendapatan perusahaan karena transaksi tidak lagi terbatas pada tempat tertentu. Perusahaan dapat mengadakan promsi kepada para pengguna Internet secara dua arah. E-business sebernarnya merupakan bentuk bisnis yang berbasis elektronik, seperti radio dan televisi. Namun karena e-business banyak dikenal masyarakat ketika menggunakan media Internet, maka pengertian e-business bergeser menjadi bisnis yang berbasis Internet.

Perkembangan teknologi terus berlanjut hingga muncul teknologi pada ponsel yang memungkinkan para penggunanya untuk mengakses Internet. Dengan demikian, pengguna dapat mengakses sistem e-business dari mana saja meskipun mobilitasnya tinggi, sehingga lahirlah mobile business (m-business). Kemudian para pakar mengembangkan sistem e-business menjadi suatu sistem yang memungkinkan para penggunanya untuk berinteraksi dengan sistem yang disebuti E-business. E-business tidak memerlukan kantor yang formal sebab hanya akan tampil diinternet sebagai sebuah situs web. Para pihak yang terkait hanya membutuhkan web service sebagai perantara 
dan kesepakatan kerja sama antara pemasok dan pihak pengelola. Begitu pula dengan kesepakatan dengan konsumen dan juga bank. Yang tidak bisa dilakukan secara online hanya proses produksi barang-barang fisik dan teknis pengirimannya.

Komponen-komponen yang harus dipenuhi dalam suatu E-business adalah Kartu kredit sebagai alat pembayaran, virtual shop yang merupakan home page yang menampilkan produk-produk yang ditawarkan dan jalur pembayaran yang jelas, untuk memberi jaminan diterimanya bayaran dari konsumen kepada perusahaan. Sejak Internet digunakan sebagai sarana bisnis pada tahun 1990-an, denyut nadi kehidupan perusahaan seakan tidak pernah terhenti. Toko-toko virtual dibuka selama 24 jam selama 7 hari dalam seminggi untuk melayani transaksi. Fungsi e-bussiness adalah untuk mendukung bagian pemasaran, produksi, accounting, keuangan dan human resource management. Dengan menerapkan e-business, perusahaan seakan membuka toko di berbagai daerah bahkan negara karena konsumen dari berbagai belahan dunia dapat mengakses situs webnya dan melakukan transaksi kapan saja dan tanpa harus meninggalkan rumahnya yang komputernya terhubung dengan Internet.

Selain itu, perusahaan dapat berkomunikasi secara langsung tanpa harus melalui birokrasi yang rumit. Salah satu nilai implementasi dari e-business adalah tercapainya nilai cyber space yang memungkinkan orang untuk berbelanja beraneka ragam produk ke berbagai lokasi hanya melalui komputer pribadinya. Manajemen rantai suplai atau (SCM) menurut Harland pada tahun 1996 adalah pengelolaan suatu jaringan bisnis yang saling berhubungan yang terlibat dalam penyediaan akhir paket-paket produk dan layanan yang diperlukan oleh konsumen akhir. Supply meliputi manajemen rantai semua gerakan dan penyimpanan bahan baku, bekerja dalam persediaan-proses dan barang jadi dari titik asal ke titik konsumsi (rantai suplai). Definisi lain yang disediakan oleh Kamus APICS ketika mendefinisikan SCM sebagai "perencanaan desain, pengendalian pelaksanaan dan monitoring kegiatan rantai pasokan dengan tujuan untuk menciptakan nilai bersih, membangun infrastruktur yang kompetitif, meningkatkan logistik di seluruh dunia, sinkronisasi pasokan dengan permintaan dan mengukur kinerja secara global”. 


\section{A. Value Chain: pembelian secara elektronik (Electronic Purchasing)}

Value chain (rantai nilai) adalah strategi dalam memandang bisnis yang dilihat sebagai rantai aktivitas yang mengubah input menjadi output yang bernilai bagi pelanggan. Nilai bagi pelanggan yang merupakan hasil dari aktivitas perusahaan dibagi menjadi tiga, yaitu:

- Aktivitas yang mampu membedakan produk dengan produk pesaing

- Aktivitas yang mampu menurunkan biaya produk

- Aktivitas yang mampu memenuhi kebutuhan pelanggan

Kerangka value chain memiliki dua syarat untuk dapat digunakan sebagai salah satu alat analisis manajemen biaya. Sehingga perusahaan dapat mengambil keputusan strategis dalam menghadapi persaingan bisnis yang semakin ketat, Syarat-syarat tersebut adalah:

- Data biaya setiap aktivitas sebagai pendukung analisis value chain,

- Informasi untuk mendukung analisis product life cycle (daur hidup produk).

\section{Tujuan Penerapan Value Chain}

Perusahaan menerapkan value chain ini bertujuan untuk mengidentifikasi aktivitasaktivitas dalam sistem produksi sehingga dapat diketahui kelemahan dan kekurangan aktivitas yang terdapat dalam perusahaan.

Analisis value chain merupakan strategi yang dapat digunakan perusahaan untuk membangun nilai perusahaan kearah yang lebih baik. Analisis ini dapat membantu perusahaan untuk lebih fokus pada rencana strategi (renstra) yang dipilih sehingga mampu meraih keunggulan kompetitif. 
Gambar di bawah ini menjelaskan jenis kerangka rantai nilai yang umum.

Skema Rantai Nilai

\begin{tabular}{|c|c|c|c|c|}
\hline \multicolumn{3}{|c|}{ Manajemen sumber daya manusia } \\
\hline \multicolumn{3}{|c|}{ Riset, teknologi, dan pengembangan sisitem } \\
\hline $\begin{array}{c}\text { Pengadaan } \\
\text { logistic } \\
\text { dalam } \\
\text { perusahaan }\end{array}$ & Operasi & $\begin{array}{c}\text { Pengadaan } \\
\text { logistik luar } \\
\text { perusahaan }\end{array}$ & $\begin{array}{c}\text { Pemasaran } \\
\text { dan } \\
\text { Penjualan }\end{array}$ & Layanan \\
\hline
\end{tabular}

Sumber: Pearce dan Robinson 2008, dengan modifikasi

Aktivitas value chain ini dibedakan menjadi dua aktivitas, yaitu:

1) Aktivitas primer (utama), yaitu aktivitas-aktivitas yang berhubungan dengan penciptaan produk, pemasaran, dan pengiriman ke pembeli serta pelayanan setelah purna jual. Misalnya logistik kedalam, operasi, logistik keluar, pemasaran dan penjualan, dan pelayanan.

2) Aktivitas pendukung, yaitu aktivitas-aktivitas yang membantu operasional perusahaan secara keseluruhan dengan menyediakan insfrastruktur sehingga aktivitas primer dapat berjalan secara keberlanjutan. Misalnya administrasi umum, manajmen sumber daya manusia, teknologi dan pengembangan sistem, dan pembelian.

\section{Metode Analisis Rantai Nilai}

Analisis value chain digunakan oleh analisis internal perusahaan untuk membantu memahami posisi suatu perusahaan atau organisasi yang dijalani agar mampu memenuhi kebutuhan pelanggan dan mencapai keunggulan kompetitif.

Ketika perusahaan mampu unggul dan kompetitif artinya perusahaan mampu menciptakan nilai lebih untuk pelanggannya. Dengan begitu perusahaan dapat memperoleh keuntungan yang lebih tinggi karena produk yang dihasilkan lebih laku dan lebih unggul dibandingkan competitor lain. 
Perusahaan harus dapat membuat pilihan yang terbaik mengenai apa saja yang yang menjadi kebutuhan pelanggan dan bagaimana memenuhi kebutuhan atau permintaan pelanggan. Sehingga perusahaan memerlukan suatu strategi dalam hal ini analisis value chain untuk menentukan keunggulan kompetitif dan menemukan cara untuk mencapai keunggulan tersebut.

\section{B. Manajemen Rantai Pasok (Supply Chain Management)}

Manajemen rantai pasokan merupakan proses yang terintegrasi dari keseluruhan kegiatan pergerakan produk atau jasa dari pemasok ke pelanggan yang meliputi informasi, dana, serta sumberdaya lainya yang saling terkait.

Kegiatan-kegiatan pengelolaan rantai pasok dilakukan mulai dari pengadaan bahan baku, perencanaan kolaboratif, penyebaran informasi, pengiriman pesanan, penelusuran pesanan, layanan pasca penjualan, pengukuran kinerja perusahaan, hingga pengembangan produk terbaru.

Segala aktivitas tersebut bertujuan untuk memastikan bahwa pemenuhan permintaan pasar bisa tercukupi, dengan melakukan mengintegrasikan perpindahan barang dengan para pihak terkait, baik dari pemasok, distributor, penyedia layanan pihak ketiga, maupun konsumen.

Dalam artikel kali ini mari kita simak jenis sistem rantai pantok serta bagaimana mengelolanya:

\section{Jenis-Jenis Sistem Rantai Pasok}

Dalam melakukan manajemen rantai pasokan, terdapat 3 komponen yang kegiatan yang dilakukan. Ketiga sistem tersebut yaitu:

1. Upstream supply chain, yaitu pengelolaan perpindahan produk yang dilakukan antara perusahaan dengan vendor penyedia bahan baku.

2. Downstream supply chain, yaitu pendistribusian produk dari perusahaan ke konsumen. Biasanya, proses ini dilakukan langsung oleh perusahaan tanpa menggunakan jasa vendor penyetok barang.

3. Internal supply chain, yaitu pengelolaan ketersediaan bahan baku, pasokan bahan baku, serta proses pabrikasi yang dilakukan oleh sistem manajemen. 


\section{Proses Manajemen Rantai Pasokan}

Untuk bisa mengelola rantai pasokan perusahaan, ada beberapa proses yang harus dilakukan. Diantaranya adalah:

\section{1) Pelanggan melakukan pesanan}

Dalam sebuah bisnis manufaktur, khususnya perusahaan yang berorientasi pada Original Equipment Manufacture, pelanggan merupakan mata rantai pertama. Proses pengelolaan rantai pasok baru bisa dilakukan apabila pesanan dari pelanggan masuk ke perusahaan.

\section{2) Perencanaan}

Dari pesanan pelanggan yang masuk, perusahaan mendapatkan informasi penting seperti tanggal penerimaan produk, serta jumlah pesanan. Dari situ, dibuatlah sebuah perencanaan produksi barang yang dipesan konsumen. Perencanaan yang dilakukan meliputi bahan-bahan yang dibutuhkan dalam produksi, serta penjadwalanya.

\section{3) Pembelian}

Setelah rencana sudah jadi dan matang, departement purchasing melakukan pesanan bahan baku dan bahan pendukung yang sudah direncanakan sebelumnya. Mereka harus menetapkan jadwal penerimaan barang serta jumlah yang dibutuhkan.

4) Inventory

Bahan baku dan bahan pendukung yang diterima perusahaan harus melalui proses uji kualitas dan ketetapan terlebih dahulu. Setelah itu, barang masuk ke dalam gudang.

5) Produksi

Proses manajemen rantai pasokan yang terahir adalah produksi. Bahan mentah yang sudah siap kemudian dikeluarkan dari gudang dan dimulailah proses produksi pesanan pelanggan.

- Pemrosesan order elektronik

- Penanganan dan pelayanan kepada pelanggan

- Kerja sama dengan mitra bisnis 


\section{Pemrosesan order elektronik}

Pemrosesan order elektronik adalah sebuah kegiatan pemrosesan pemesanan yang di lakukan secara otomatis yang memanfaatkan perangkat elektronik atau dengan internet sehingga perusahaan dapat langsung berinteraksi dengan customer, supplier maupun rekan bisnis melalui sistem pemrosesan data internal dan eksternal secara lebih efisien dan fleksibel.

\section{Penanganan dan pelayanan kepada pelanggan}

Pelanggan merupakan salah satu yang terpenting dalam menjalankan suatu bisnis, tanpa pelanggan bisnispun tidak akan berjalan dan berhenti, untuk turus menjaga pelayanan yang baik terhadapa pelanggan beberapa ini adalah cara yang perlu dilakukan:

a. Kenali pelanggan Anda

Mengetahui pelanggan Anda memberi Anda kesempatan untuk memberikan perawatan yang dipersonalisasi kepada mereka.Anda mungkin harus melakukan survei, berhubungan dengan mereka melalui kehadiran media sosial Anda, mengajukan pertanyaan kepada mereka, mendengarkan mereka dan berusaha memahaminya, tapi ingat, jangan membuat asumsi. Ketika Anda melakukan upaya ekstra untuk melayani pelanggan Anda lebih baik, mereka akan kembali.

b. Perbaiki kesalahan Anda

Tujuannya adalah untuk mempertahankan tingkat kepuasan pelanggan yang tinggi setiap saat. Bahkan ketika Anda bersalah secara tidak langsung, kadangkadang ada baiknya untuk masuk untuk memperbaiki masalah hanya demi memastikan bahwa pelanggan Anda senang dan reputasi perusahaan Anda dilindungi.

c. Bijaklah

Isyarat yang bijaksana seperti mengingat nama pelanggan, mengirimkan ucapan terima kasih bersama dengan pesanan atau merayakan ulang tahun pelanggan mungkin tampak sederhana atau bahkan tidak signifikan, tetapi mereka dapat membuat perusahaan Anda disayangi oleh klien Anda.

d. Tanggapi pertanyaan dengan cepat

Konsumen menghargai kecepatan pengiriman seperti halnya mereka menghargai memiliki produk atau layanan mereka dalam serangkap. 


\section{E. Kerja sama dengan mitra bisnis}

Pengertian mitra bisnis adalah rekan/partner dalam mengadakan bisnis. Setiap operasional bisnis, seperti mengatur SDM, mengelola arus keuangan, mempersiapkan infrastruktur perusahaan, dan hal lainnya bisa dikerjakan bersama rekan bisnis.

Ada banyak cara untuk menjadi sukses. Salah satunya adalah dengan mengadakan kerjasama dengan mitra bisnis. Ya, menjalankan bisnis juga tidak bisa terlepas dari peran kamu sebagai mahluk sosial yang membutuhkan orang lain.

Beberapa faktor berikut ini akan membantu kamu untuk membuat kerjasama bisnis berjalan sukses sehingga semua target tercapai.

- Buat visi dan misi bersama

- Identifikasi serta manfaatkan kekuatan diri dan mitra

- Tentukan peran kerja masing-masing

\section{* Business to Business (perdagangan antar pelaku usaha bisnis)}

Business to Business (B2B) merupakan penjualan produk atau jasa yang diberikan oleh satu bisnis dan diperuntukan untuk bisnis lainnya, bukan kepada konsumen. Sebagai contoh, jika Anda menjalankan bisnis yang menjual bahan pakaian dan Anda melakukan penjualan ke store-store atau bisnis fashion yang ada. Inilah yang disebut dengan B2B karena bisnis atau jasa Anda diperuntukkan untuk perusahaan lain, bukan langsung kepada perorangan atau grup.

\section{* Business to Consumer (perdagangan antar pelaku usaha bisnis dengan konsumen)}

Business to Customer (B2C) merupakan bisnis yang melakukan pelayanan atau penjualan barang atau jasa kepada konsumen perorangan atau grup secara langsung. Dengan kata lain, bisnis jenis ini berhubungan langsung dengan konsumen bukan perusahaan atau bisnis lainnya. Sebagai contohnya, Anda memiliki bisnis makanan. Lalu ketika Anda menjual makanan kepada konsumen perorangan, berarti bisnis Anda B2C. Tetapi jika Anda menjual makanan dalam jumlah besar kepada bisnis lainnya, berarti bisnis Anda adalah B2B. 


\section{Consumer to Business (perdagangan antar konsumen dengan pelaku bisnis atau}

perusahaan)

Consumer-to-business (C2B) adalah transaksi atau kegiatan pemasaran lainnya yang berasal dari konsumen dan diarahkan ke bisnis. Ini biasanya sering kita lihat di saluran pemasaran online, meskipun tidak selalu. Internet memfasilitasi konsumen kemampuan lebih baik untuk bertransaksi dengan bisnis secara efektif dan efisien dibandingkan dengan apa yang biasanya dimungkinkan melalui saluran transaksi tradisional.

Model bisnis C2B melibatkan konsumen (individu) yang menciptakan nilai dan bisnis mengkonsumsi nilai itu. Sebagai contoh, ketika seorang konsumen menulis ulasan atau ketika seorang konsumen memberikan ide yang berguna untuk pengembangan produk baru maka konsumen tersebut menciptakan nilai untuk bisnis jika bisnis mengadopsi input dari individu tersebut.

* Intrabusiness e-business (perdangan dalam lingkup intranet perusahaan yang melibatkan pertukaran barang, jasa, dan informasi

Penggunaan E Commerce dalam lingkup internal perusahaan atau organisasi untuk meningkatkan kinerja dan operasi. 